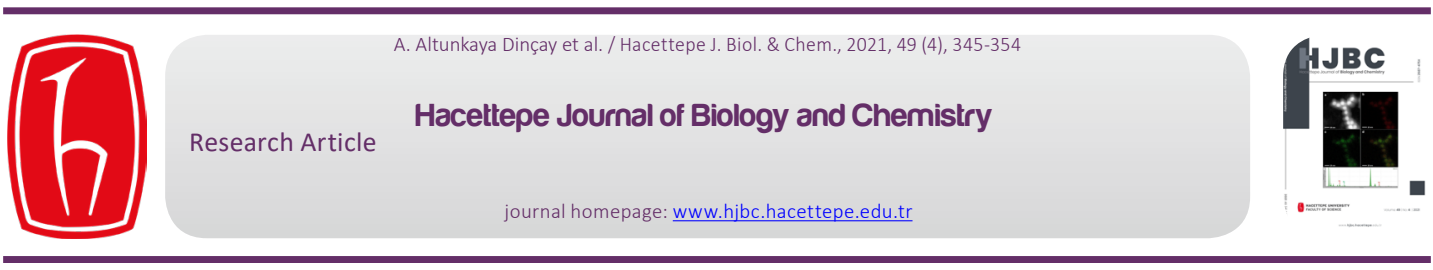

\title{
Effect of Various Inhibitors on Enzymatic Browning, Antioxidant Activity and Total Phenol Content of Fresh-Cut Rocket Salad (Eruca Sativa Mill.)
}

\section{Taze Kesilmiş Roka Salatasının (Eruca Sativa Mill.) Enzimatik Esmerleşmesi, Antioksidan Aktivitesi ve Toplam Fenolik Bileşik İçeriğine Farklı İnhbitörlerin Etkisi}

\author{
Arzu Altunkaya Dinçay $y^{1,2}$ \\ ${ }^{1}$ Ministry of Agriculture and Foresty, General Directorate of Food and Control, Ankara, Turkey. \\ ${ }^{2}$ Lokman Hekim University, Faculty of Health Sciences, Human Nutrition and Dietetics Department, Ankara, Turkey.
}

\section{A B STRACT}

n this study, polyphenol oxidase (PPO) was extracted and partially purified by ion-exchange chromatography on a column packed with diethyaminoethyl cellulose (DEAE) from fresh rocket salad. Its optimum temperature and $\mathrm{pH}$ were found to be $30^{\circ} \mathrm{C}$ and 6.0 , respectively. Rocket PPO was shown to the greatest substrate specificity with catechol among the substrates used. Ascorbic acid, cysteine, oxalic acid and citric acid were tested as potential inhibitors of rocket PPO. Cysteine was found as the most effective inhibitor. While ascorbic acid increased the total antioxidant activity of rocket significantly, Rocket phenolics were protected from oxidation by the treatments of these inhibitors.

\section{Key Words}

Rocket salad (Eruca sativa Mill.), enzymatic browning, phenolic compounds, inhibitors.

u çalışmada, taze roka salatasında bulunan polifenoloksidaz (PPO), dietilaminoetil selüloz (DEAE) ile doldurulmuş kolon üzerinden kısmen saflaştırılmıştır. Optimum sıcaklığı $30^{\circ} \mathrm{C}$ ve pH 6.0 olarak bulunmuştur. Roka PPO, en yüksek substrat spesifikliğini kullanılan substratlar arasında kateşol ile göstermiştir. Askorbik asit, sistein, okzalik asit ve sitrik asit potansiyel inhbitörler olarak test edilmiştir. En etkili inhibitor sistein olarak belirlenmiştir. Askorbik asit toplam antioksidan aktiviteyi arttırken, kullanılan inhibitörlerin Rokada bulunan fenolik bileşiklerin oksidasyonunu önlediği tespit edilmiştir.

\section{Anahtar Kelimeler}

Roka salatası (Eruca sativa Mill.), enzimatik esmerleşme, fenolik bileşikler, inhibitörler.

Article History: Received: Nov 19, 2019; Revised: Jan, 2021; Accepted: Mar 15, 2021; Available Online: Jun 1, 2021.

DOI: https://doi.org/10.15671/hibc. 649050

Correspondence to: A.A. Dinçay; Ministry of Agriculture and Foresty, Ankara, Turkey.

E-Mail: arzualtunkaya@gmail.com 


\section{INTRODUCTION}

D iets rich in fruits and vegetables are associated with a lower risk of cancer and cardiovascular diseases [1]. These beneficial effects are believed to be due to vitamins and phytochemicals such as ascorbic acid, carotenoids, polyphenols and fibre that may protect key biological constituents such as lipoproteins, membranes, and DNA [2].

This evidence prompted health bodies to suggest an increase of the dietary intake of fruits and vegetables. However, nowadays many people do not want to spend much time preparing vegetable foods every day, and so they frequently use fresh-cut vegetables, which are horticultural products subjected to minimal processing which was described as "cleaning, washing, cutting and packaging". The key criteria to consider a vegetable or fruit as a fresh-cut product include that the tissue is in a living, respiring physiological state [3]. Fresh-cut products are subject to rapid deterioration and short shelf life as compared to intact products. The alterations are the direct result of the wounding associated with processing, which leads to physical and physiological changes that strongly affect the quality of the product [4]. An important alteration induced by cutting is the browning of the tissues that is a direct consequence of polyphenol oxidase (PPO) action on endogenous polyphenols in the presence of oxygen $[5,6]$.

Different treatments have been evaluated to reduce browning in fresh-cut products, such as the application of antioxidant compounds (e.g., sulfites), calcium salts to maintain membrane integrity, chemical inhibitors of PPO and/or POD, or the use of modified atmosphere packaging to exclude oxygen [6]. Since, some browning inhibitors may also act as antioxidant compounds, the addition of antioxidants has become increasingly popu$\operatorname{lar}[7]$.

Among different leafy vegetables, rocket is one of the most popular vegetables in Mediterranean Countries and well known for its pleasant bitter taste. This vegetable has good nutritional value, being a rich source of vitamins (especially $A$ and $C$ ), minerals, such as calcium and iron, and several antioxidants such as flavonoids. Hydroxycinnamic and kaempferol derivatives have been previously identified in rocket [8]. Rocket is a rich source of glycosylated flavonoids: these are glucoraphanin, glucoalyssin, progoitrin and dimeric glucosativin.
Morever, Degl'Innocenti et al. [8] found that flavonoid content of fresh-cut rocket salad was influenced during storage.

In this study, PPO was partially purified from rocket salad. The effect of different substrates and inhibitors on PPO activity, total antioxidant activity and total phenol content were investigated.

\section{MATERIAL and METHOD}

\section{Materials}

Rocket salad (Eruca sativa Mill.) was obtained from a local market in Copenhagen, Denmark. Oxalic acid, ascorbic acid, cysteine, citric acid, ammonium sulphate, sodium chloride, were purchased from Merck (Darmstad, Germany). Chlorogenic acid, and caffeic acid were obtained from Sigma-Aldrich (Steinheim, Germany). All other chemicals used were of analytical grade.

\section{Methods \\ Preparation of purified PPO extract}

Enzyme was extracted by mixing $40 \mathrm{~g}$ rocket salad leaves with $90 \mathrm{~mL}$ of phosphate buffer $(\mathrm{pH} 7.0)$ and $1 \%$ polyvinylpyrrolidone (PVPP) in a homogenizer (Homogenizer Standard Unit, Labworld-Online.com, Straufen, Germany) for $30 \mathrm{~min}$. The mixture was centrifuged at $25.000 \times g$ for $15 \mathrm{~min}$ at $4^{\circ} \mathrm{C}$. The supernatant containing PPO (crude extract) was further purified by means of ion exchange chromatography.

A column packed with DEAE-cellulose $(10 \times 2.5 \mathrm{~cm})$ was used for ion exchange chromatography. Packed column was washed and balanced with $0.067 \mathrm{M}$ phosphate buffer ( $\mathrm{pH}$ 7.0) before use. Crude enzyme extract was loaded onto the column. The column was eluted with the same buffer and linear gradient of $\mathrm{NaCl}$ concentration from 0 to $1 \mathrm{M}$ by increasing steps 0.1 at room temperature. The fractions having PPO activity were collected and degree of purification was determined by measuring specific activity before and after purification. Specific activity was determined from PPO activity and quantitative protein determination using the Bradford protein dye-binding method with bovine serum albumin as a standard [9]. The eluate fractions were collected as $5 \mathrm{~mL}$ aliquots and assayed for their PPO activities.

\section{PPO activity assay}

PPO activity was measured using the method described by us with minor modifications [9]. Enzyme extract (25 
$\mu$ ) was added into $0.3 \mathrm{ml}$ of $10 \mathrm{mM}$ catechol solution in $0.067 \mathrm{M}$ phosphate buffer $(\mathrm{pH} 7.0)$ to initiate the reaction (final volume was $2.5 \mathrm{ml}$ ). Initial rate of quinone formation was monitored at room temperature as an increase in absorbance at $420 \mathrm{~nm}$ using UV-Vis spectrophotometer (HP 8453) with a $1 \mathrm{~cm}$ path-length cuvette. PPO activity was defined as increase in absorbance per minute in $1 \mathrm{ml}$ of reaction mixture $\left(\Delta \mathrm{A}_{420} / \mathrm{min} / \mathrm{ml}\right)$.

\section{Effect of $\mathrm{pH}$ and temperature on PPO activity}

Enzyme activity, as a function of $\mathrm{pH}$, was determined with $10 \mathrm{mM}$ catechol in $0.067 \mathrm{M}$ phosphate buffer, ranging from $\mathrm{pH} 4.0$ to 9.0. The $\mathrm{pH}$ stability was determined by incubating the enzyme in $0.067 \mathrm{M}$ phosphate buffer ( $\mathrm{pH}$ 4.0-9.0) for $30 \mathrm{~min}$. PPO activity as a function of temperature was also determined at various temperatures from $10-70^{\circ} \mathrm{C}$. PPO activity was assayed under the conditions mentioned above using catechol as the substrate.

\section{Substrate specificity and enzyme kinetics}

Michaelis-Menten constant $\left(\mathrm{K}_{\mathrm{m}}\right)$ and maximum reaction velocity $\left(V_{m}\right)$ were determined for five substrates (catechol, catechin, chlorogenic acid, caffeic acid, 4-methyl catechol). Data were plotted as $1 / \mathrm{V}$ and $1 / \mathrm{S}$ concentration according to the method of Lineweavear Burk [10].

\section{Inhibitor effects}

The effects of several inhibitors (ascorbic acid, cysteine, citric acid, oxalic acid) on rocket PPO activity were studied. PPO activities were measured th two inhibitor concentrations. Values $1 / \mathrm{V}$ and $1 / \mathrm{S}$ were employed to Line-weaver Burk graphs. Finally, $\mathrm{K}_{\mathrm{i}}$ values were obtained from graphs.

\section{Reduction of Fremy's salt radical}

The antioxidative activity values of fresh-cut rocket salad treated with various PPO inhibitors (ascorbic acid, cysteine, citric acid and oxalic acid) were determined as their ability to reduce the stable radical Fremy's salt as measured by electron spin resonance (ESR). Rocket salad (4 g) was homogenised in $9 \mathrm{ml}$ of distilled water, ascorbic acid $(0.01 \%)$, cysteine $(0.01 \%)$, citric acid (0.01\%), and oxalic acid (0.01\%) solutions, respectively. Aliquots were taken from the homogenate at 0, 1, 2, 4 6 and $24 \mathrm{~h}$. Homogenate was exposed to air and stored at $4^{\circ} \mathrm{C}$. The homogenate was centrifuged at $15,000 \mathrm{~g}$ for $15 \mathrm{~min}$. The supernatants were mixed with $200 \mathrm{~mL}$ of a solution of Fremy's salt $(820 \mu \mathrm{M})$ in $25 \%$ saturated sodium carbonate solution. The mixture was left for 5 min before an ESR spectrum was recorded on an ESR Miniscope MS 100 (Magnettech, Berlin, Germany). The measurements were carried out at room temperatures. The instrument settings were as follows: centre field, 3366.90 G; sweep width, 30 G; sweep time, 30; modulation amplitude, $1.0 \mathrm{G}$ and microwave power, $10 \mathrm{~mW}$. Software analyses (Magnettech, Berlin, Germany) were employed to obtain the areas under the ESR spectra by double integration.

\section{Total phenol content}

Total amount of phenols was determined by using Folin-Ciocalteu's phenol reagent and spectrophotometric determination [11]. Rocket salad (4 g) was homogenised in $9 \mathrm{ml}$ of distilled water, ascorbic acid $(0.01 \%)$, cysteine (0.01\%), citric acid $(0.01 \%)$, and oxalic acid $(0.01 \%)$ solutions, respectively. Samples were taken from the homogenate at 0, 1, 2, 6 and $24 \mathrm{~h}$. Homogenate was exposed to air and stored at $4^{\circ} \mathrm{C}$. The homogenate was centrifuged at 15,000 g for $15 \mathrm{~min}$. The supernatants were used for subsequent determination of phenol content. Total phenol content was determined using Folin-Ciocalteu reagent according to the method by 10-Amerine and Ough, 1980. One hundred microliter of the supernatant was mixed with $30 \mathrm{~mL}$ of Milli-Q-water, and 2.5 $\mathrm{mL}$ Folin-Ciocalteu's phenol reagent was subsequently added followed by $7.5 \mathrm{~mL}$ of a $20 \%$ sodium carbonate solution, and the total volume was adjusted to $50 \mathrm{~mL}$ with Milli $\mathrm{Q}$ water. The reaction mixture was stored at room temperature for $2 \mathrm{~h}$ before measuring the absorbance at $765 \mathrm{~nm}$ on a Cintra 40, UV-Visible spectrophotometer (GBC scientific equipment, Arlington Heigts, IL, USA). A standard curve based on gallic acid was used for conversion of the absorbance to phenol concentration in gallic acid equivalent (GAE).

\section{RESULTS and DISCUSSION}

\section{Extraction and purification of PPO from rocket}

In this study, simple purification protocols are proposed for separation. The stability of each enzyme varied in response to factors such as storage time, temperature, $\mathrm{pH}$, ions present in buffer solutions and the presence of protective agents and detergents. In this way, an important problem to be solved before the development of a purification procedure from a plant homogenate is to remove or inactivate plant cell secondary metabolites which hinder the recovery of the enzymes and strongly lower the yield. Tissue homogenization during 
the isolation of PPO enzymes, whose intermediates (quinones) may also form covalent linkages that may not be reversible, initiates browning reactions [12]. Thus, the undesirable effects of degradation of polyphenolic compounds were prevented by the addition of PVPP during the homogenization of rocket tissue to obtain the crude enzyme extract. DEAE ion-exchange chromatography was selected to remove the contaminating proteins and to purify different oxidative enzymes in rocket. Purification of enzymes was carried out by contacting an impure liquid enzyme preparation containing enzyme and soluble impurities (hinder the recovery of the enzymes and strongly lower the yield) with DEAE in a column. Thus, the soluble impurities are preferentially adsorbed by DEAE and the adsorbed enzyme is displaced from the DEAE to produce a purified liquid enzyme preparation containing higher enzyme activity than before purification $[13,14]$. Enzyme isolation by any of the precipitation methods is normally followed by chro- matographic separation. Denaturation or loss in activity of enzymes during extraction could occur. Therefore, adsorption to ion exchanger could be appropriate and can achieve adequate concentration of diluted protein solutions [15].

Rocket PPO enzymes in the crude extract were purified on an ion-exchange column packed with DEAE-cellulose applying a concentration gradient (from 0 to $1 \mathrm{M} \mathrm{NaCl}$ ) to further understand the characteristics of these enzymes. The PPO was purified 21.23 fold with a $28.13 \%$ total recovery of the activity by the procedure. Specific activity was $0.106 \mathrm{U} / \mathrm{mg}$ proteins in crude extract and $2.25 \mathrm{U} / \mathrm{mg}$ proteins in partial purified enzyme (Table 1).

Plots of PPO activity of eluated fractions from DEAE column are shown in Fig. 1. Fractions 18-31 were pooled for the determination of purification degree.

Table 1. Partial purification of PPO enzymes.

\begin{tabular}{|c|c|c|c|c|c|}
\hline $\begin{array}{l}\text { Purification } \\
\text { steps }\end{array}$ & $\begin{array}{c}\text { Total Activity } \\
\text { (U) }\end{array}$ & $\begin{array}{l}\text { Total protein } \\
\text { (mg) }\end{array}$ & $\begin{array}{c}\text { Specific activity } \\
(\mathrm{U} / \mathrm{mg})\end{array}$ & Recovery & $\begin{array}{l}\text { Purity } \\
\text { (fold) }\end{array}$ \\
\hline Crude Extract & 2.56 & 24.21 & 0.106 & 100.00 & 1.00 \\
\hline \multicolumn{6}{|l|}{$\begin{array}{c}\text { DEAE-column } \\
\text { chromotography }\end{array}$} \\
\hline PPO & 0.72 & 0.32 & 2.25 & 28.13 & 21.23 \\
\hline
\end{tabular}

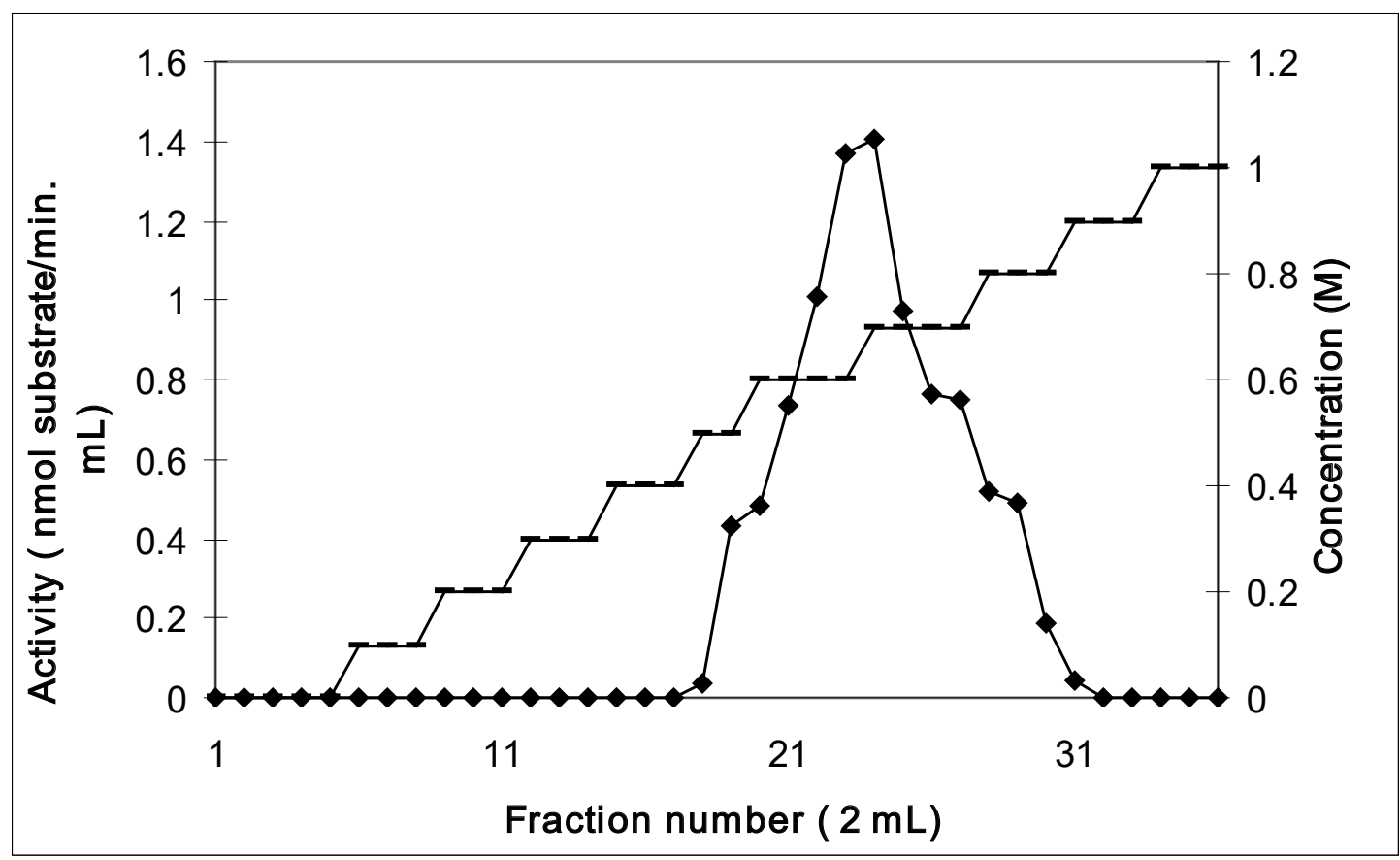

Figure 1. Purification of PPO from rocket by DEAE column chromatography. 


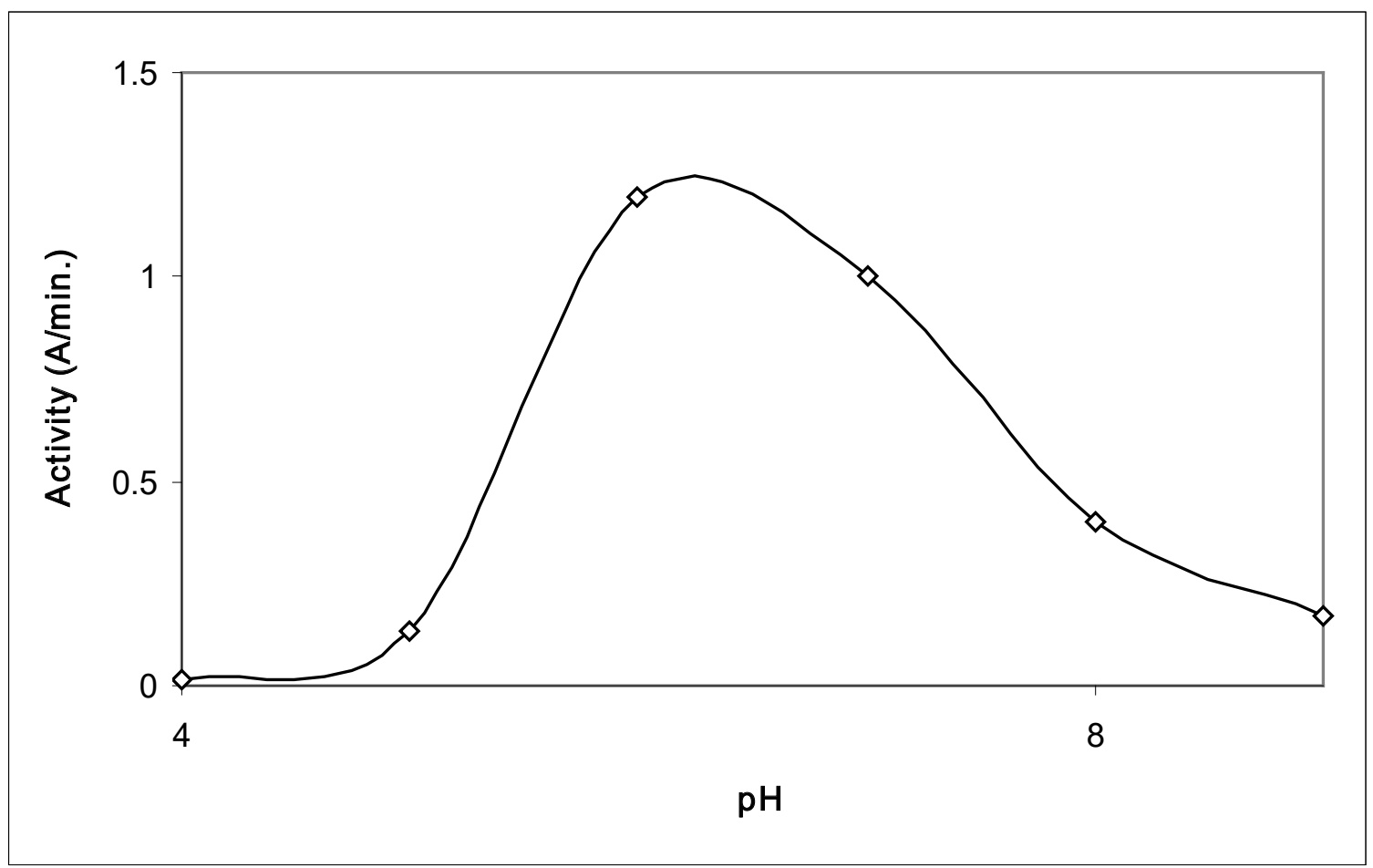

Figure 2. Change of the activity of rocket PPO with $\mathrm{pH}$.

\section{Effect of $\mathrm{pH}$ and temperature on rocket PPO activity and stability}

The activity of PPO was measured at different $\mathrm{pHs}$ and temperatures using catechol as substrate. As seen in Fig 2. an optimum $\mathrm{pH}$ of the enzyme was found to be 6.0.

In general, most plants show maximum PPO activity at or near neutral $\mathrm{pH}$ values. Differences in $\mathrm{pH}$ optima with several substrates have been reported for PPO from strawberries and other sources [16]. Aylward and Haisman [17] reported that the optimum $\mathrm{pH}$ for maximum activity of PPO varies from about 4.0 to 7.0 depending on the extraction methods, substrates and localization of the enzyme in the cell.

The $\mathrm{pH}$ stability curve of PPO activity is shown in Fig 3. The rocket PPO enzymes, at basic $\mathrm{pH}$, was more stable than acidic $\mathrm{pH}$. The $\mathrm{pH}$ stability curve indicate that PPO retained more than $90 \%$ of its original activity within $\mathrm{pH}$ range between 6.0-7.0. At the $\mathrm{pH} 5.0$ and 4.0, PPO activities decreased by about 68 and $54 \%$ of the maximum activities, respectively. At pH 9.0, only about $29 \%$ of its activity was lost. This result was similar to that for peppermint PPO, reported by Kavrayan et al. [18].
The activity profile for oxidation of catechol by rocket PPO is shown in Fig 4. The optimum temperature for the catechol reaction was $30^{\circ} \mathrm{C}$. The enzyme was stable at lower temperatures but unstable at higher temperatures. For instance, when the temperature was increased from 40 to $60^{\circ} \mathrm{C}$, the relative activity of PPO decreased from 77 to 42 . This indicated that the enzyme was rapidly denatured at higher temperatures.

\section{Kinetics and substrate specificity of rocket PPO}

Number of phenolic compounds has been shown to act as the substrates of PPO in the literature. In this study, five widely used substrates were selected (catechol, 4-methylcatechol as diphenolic substrates, chlorogenic acid, caffeic acid as a triphenolic substrate, and catechin as a pentaphenolic substrate) for specificity of rocket PPO. The Michaelis-Menten constant $\left(\mathrm{K}_{\mathrm{m}}\right)$ and maximum velocity of the reaction $\left(\mathrm{V}_{\max }\right)$ for the different substrates were determined by plotting the activity data at optimum $\mathrm{pH}$ and temperature as a function of substrate concentration according to the method of $\mathrm{Li}$ neweaver-Burk. The $K_{m}$ and $V_{\max }$ values of PPO, for each substrate, were calculated from a plot of $1 / \mathrm{V}$ versus $1 /$ 


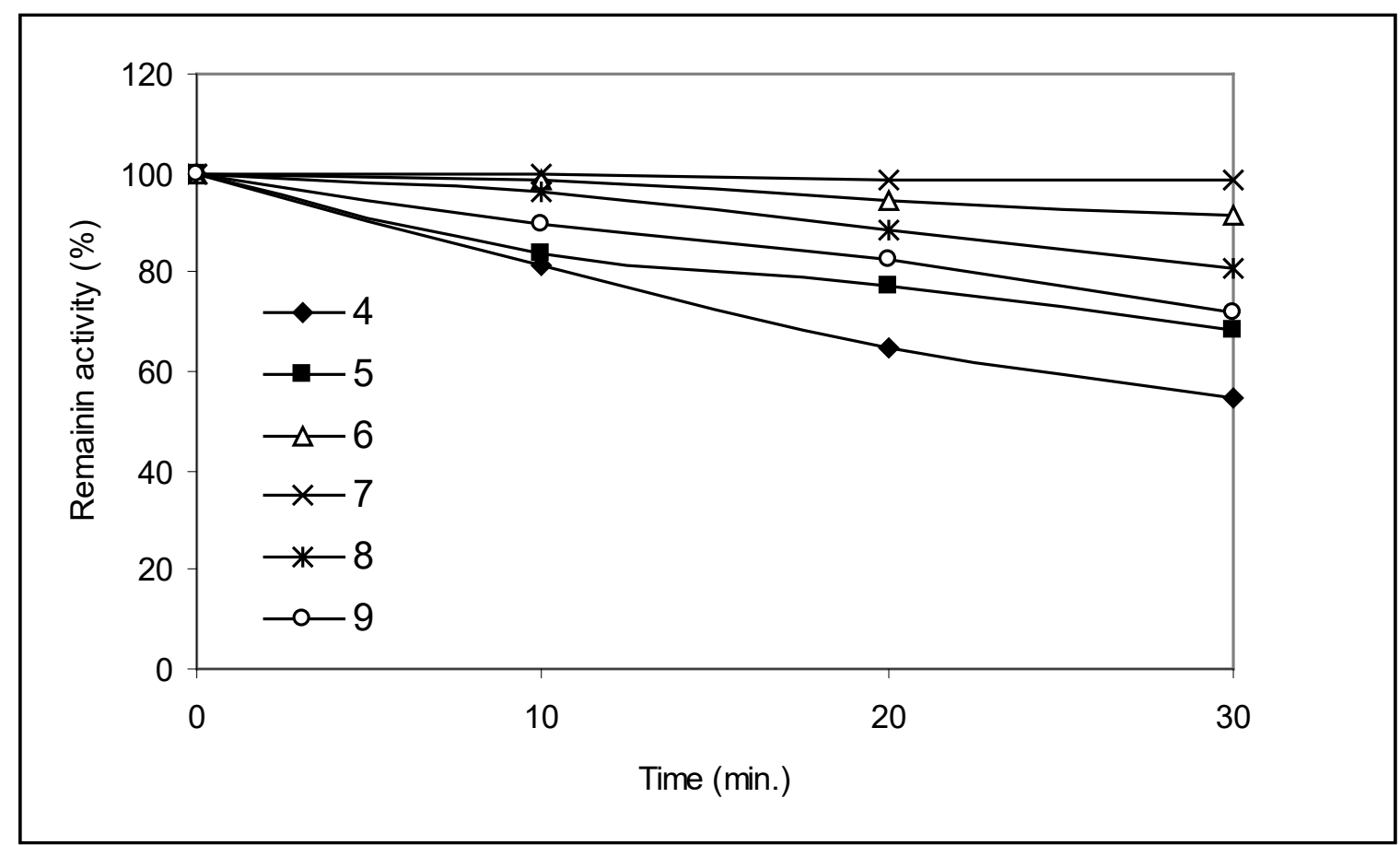

Figure 3. Change of the activity of rocket PPO with $\mathrm{pH}$ stability.

[S] and shown in Table 2. The order of affinity as substrate of rocket PPO was as follows; catechol > chlorogenic acid > catechin > 4-Methyl catechol > caffeic acid. As seen in Table 2, the PPO of rocket has the greatest efficiency toward catechol of the five substrates, taking from the highest $\mathrm{V}_{\text {max }} / \mathrm{K}_{\mathrm{m}}$ ratio into account (14.3 $\left.\mathrm{mM} / \mathrm{min}\right)$.

\section{Effect of inhibitors on rocket PPO activity}

The effects of four inhibitors namely ascorbic acid $\left(1.25 \times 10^{-2}-2.510^{-2} \mathrm{mM}\right)$, cysteine $\left(5-7.5 \times 10^{-3} \mathrm{mM}\right)$, oxalic acid $\left(8-12 \times 10^{-1} \mathrm{mM}\right)$ and citric acid $\left(8-12 \times 10^{-1} \mathrm{mM}\right)$ on rocket PPO activity were investigated in this study. The mode of inhibition and the values of inhibition constants $\left(\mathrm{K}_{\mathrm{i}}\right)$ are given in Table 3. Among others, cysteine was found as the most effective inhibitor of rocket PPO, followed by ascorbic acid, citric acid and oxalic acid. The type of inhibition was noncompetitive for ascorbic acid competitive for cysteine and un-competitive for citric and oxalic acids.
The inhibition of enzymatic browning in plants can be the result of (1) inactivation of PPO, (2) elimination of one of the substrates $\left(\mathrm{O}_{2}\right.$, polyphenols) for the reaction, and (3) the action of inhibitors on reaction products of enzyme action to inhibit the formation of colored products in secondary reactions. There are a number of inhibitors for plant PPO. Inhibition of PPO by cysteine is attributed to the stable colorless products formed by reaction with o-quinones [9]. Ascorbic acid acts more as antioxidant than as enzyme inhibitor because it reduces the initial $o$-quinone formed by the enzyme to the original diphenol before it undergoes to secondary reaction which lead to browning. Inhibition of PPO by oxalic acid and citric acid has been attributed to their binding with active site copper, to form an inactive complex. The extent of inhibition is not only influenced by oxalic acid or citric acid concentration, but also by $\mathrm{pH}$ [18]. As seen earlier, the type of inhibition depends not only on the origin of the PPO studied but also on the substrate used. 


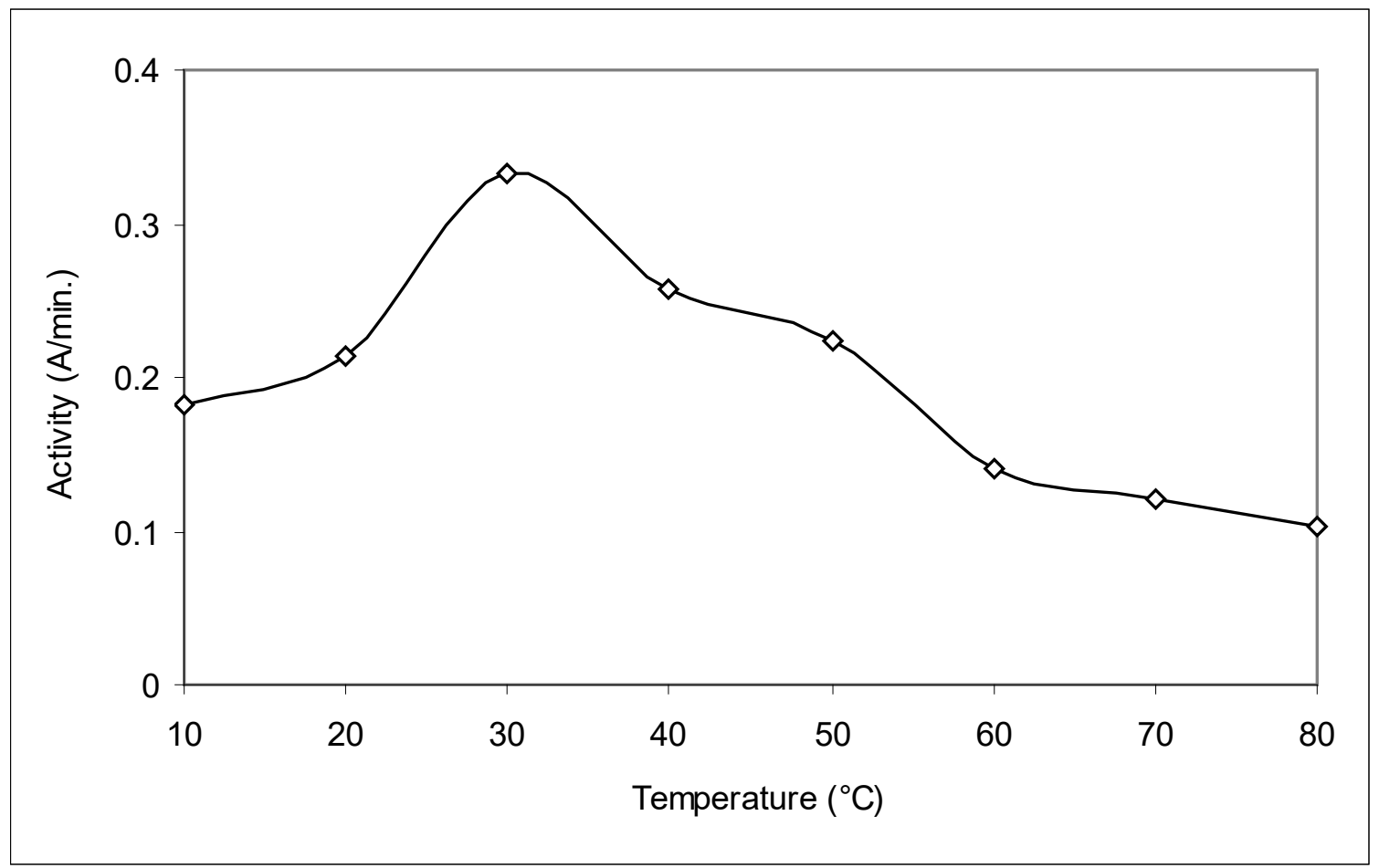

Figure 4. Change of the activity of rocket PPO with temperature.

Table 2. Substrate specificity of rocket PPO.

\begin{tabular}{cccc}
\hline Substrate & $\mathrm{V}_{\max }\left(\mathrm{min}^{-1}\right)$ & $\mathrm{K}_{\mathrm{m}}(\mathrm{mM})$ & $\mathrm{V}_{\max } / \mathrm{K}_{\mathrm{m}}$ \\
\hline 4-Methyl catechol & 3.9 & 0.6 & 6.5 \\
\hline Catechol & 5.7 & 0.4 & 14.3 \\
\hline Chlorogenic acid & 2.4 & 0.2 & 12.0 \\
\hline Caffeic acid & 1.2 & 0.7 & 1.7 \\
\hline Catechin & 2.0 & 0.2 & 10.0 \\
\hline
\end{tabular}

Table 3. Effect of various inhibitors on rocket PPO and type of inhibition.

\begin{tabular}{cccc}
\hline Inhibitor & I $(\mathrm{mM})$ & $\mathrm{K}_{\mathrm{i}}(\mu \mathrm{M})$ & Inhibition type \\
\hline Ascorbic acid & $1.25 \times 10^{-2}$ & 2.4 & Noncompetitive \\
\hline Cysteine & $2.5 \times 10^{-2}$ & & Competitive \\
\hline Citric acid & $5 \times 10^{-3}$ & 0.1 & Uncompetitive \\
\hline & $7.5 \times 10^{-3}$ & 2.5 & Uncompetitive \\
\hline Oxalic acid & $8 \times 10^{-1}$ & & 2.7 \\
\hline
\end{tabular}




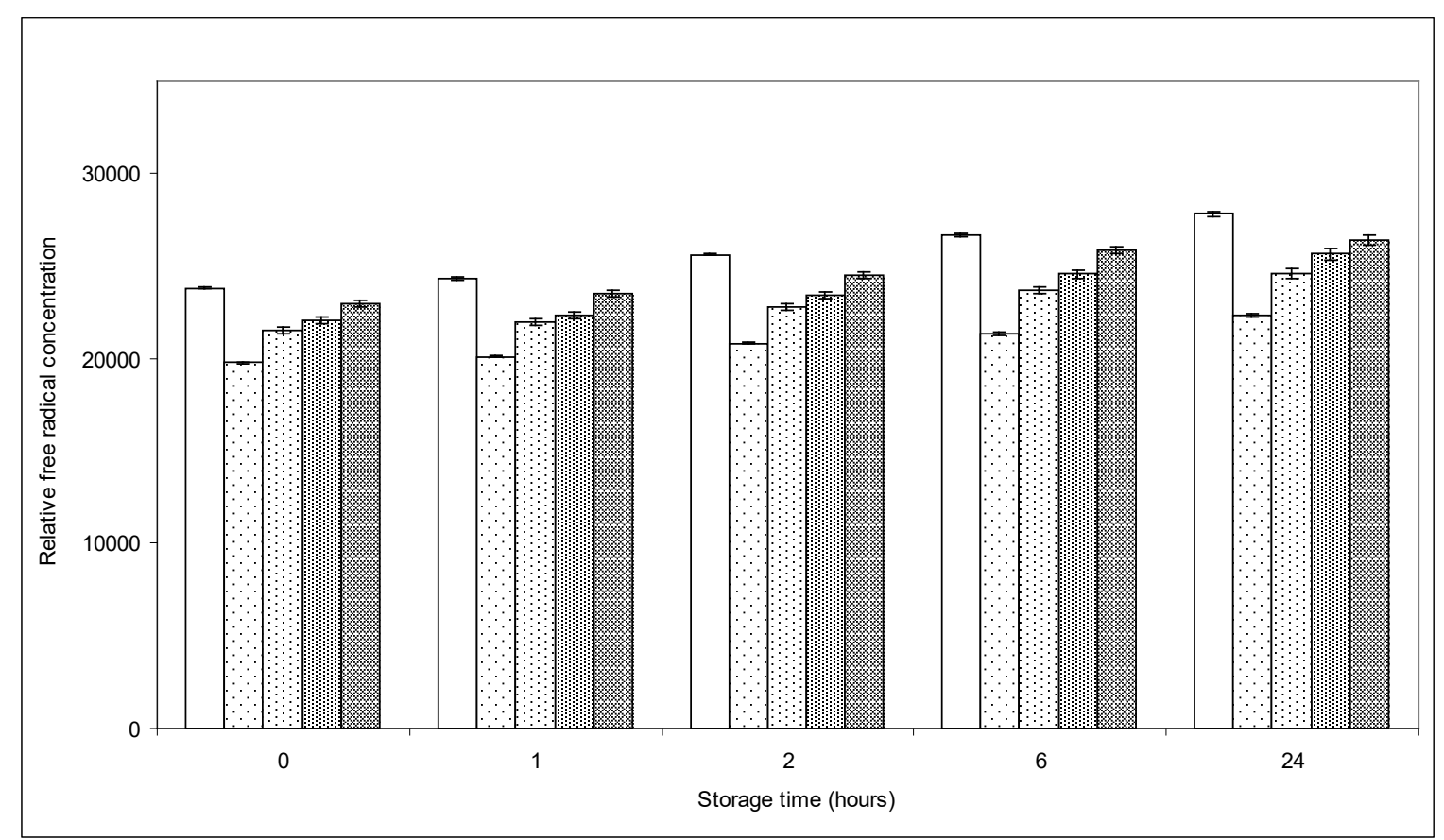

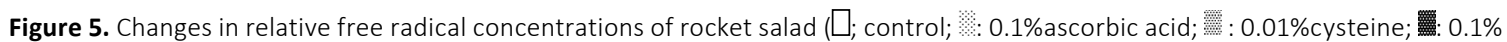
citric acid; : $0.1 \%$ oxalic acid ).

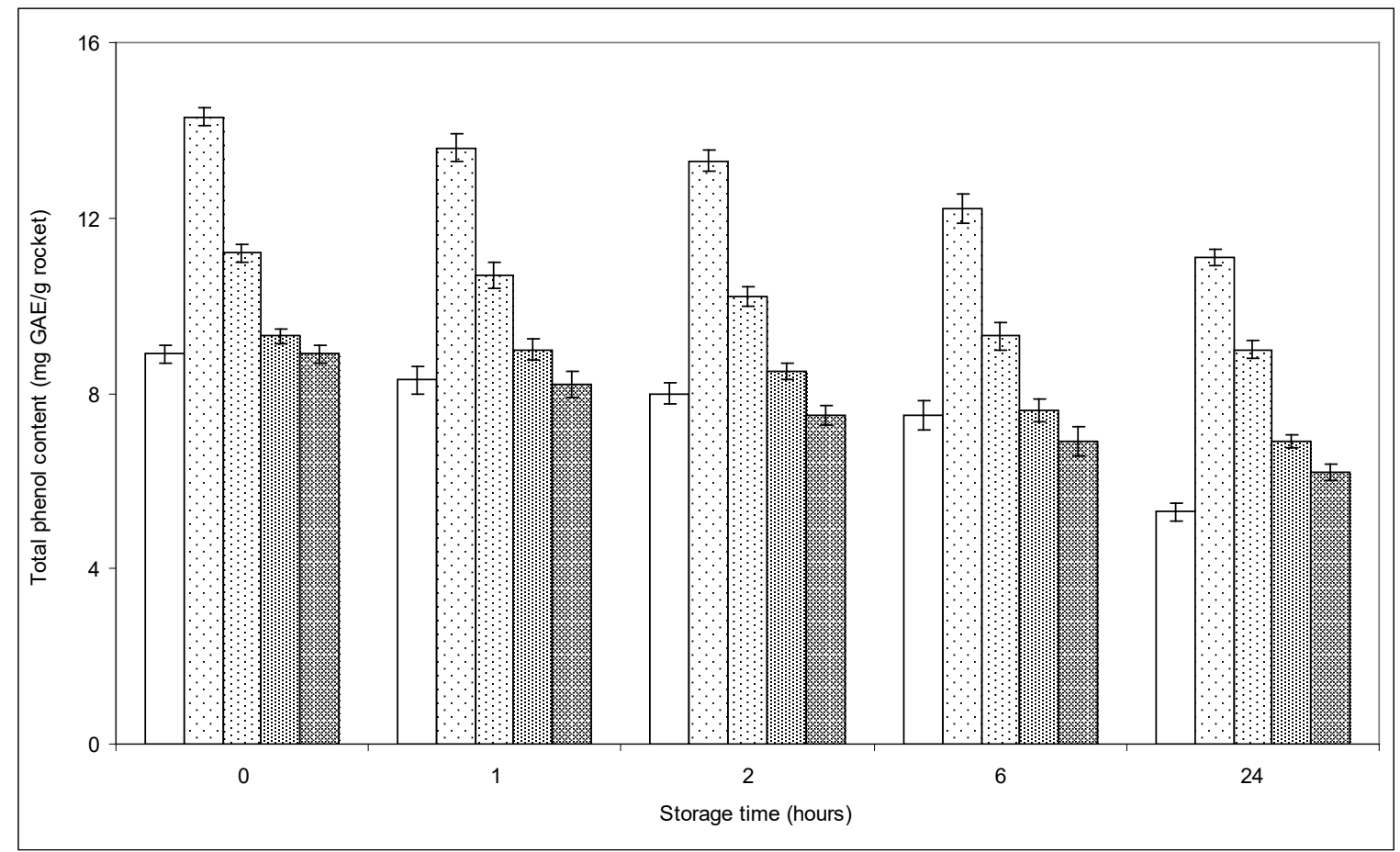

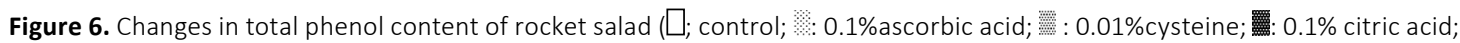
口: $0.1 \%$ oxalic acid ). 


\section{Effect of inhibitors on relative radical concentrations of rocket salad}

In this study, relative free radical concentration of rocket PPO was monitored at $4^{\circ} \mathrm{C}$ in the presence of ascorbic acid, cysteine, citric and oxalic acids. Figure 5 illustrates the change under refrigerated conditions.

The radical scavenging capacities of rocket salad samples with different inhibitors were evaluated by studying the reduction of the stable radical, Fremy's salt. The scavenging of Fremy's salt was monitored by ESR. Diamagnetic (compounds with an even number of electrons) reduction products are formed when antioxidative compounds react with Fremy's salt, leading to a decrease in the intensity of ESR signal.

The antioxidant activity of rocket salad is derived from phenolic compounds. Flavanoids (especially kaempferol and hydroxycinnamic acids derivatives) are phenol derivatives and found in substantial amounts in rocket [8]. Their potential antioxidant activity has been investigated several times. Both the number and configuration of $\mathrm{H}$-donating hydroxyl groups are the main structural features influencing the antioxidant capacity of flavanoids. This type of configuration results in higher reduction potential than flavanoid radicals. Therefore, flavanoids may inactivate these damaging species and prevent the deleterious consequences of their reactions [19]. Rocket salad tissues also contained high levels of ascorbic acid [8], which most likely accounted for the elevated antioxidant power as it was found in many plant tissues [20].

Increase in relative free radical concentrations was observed at studied temperature. Similarly, our previous work reported a decrease in the radical scavenging activity of fresh cut lettuce within 6 hours [9].

Ascorbic acid acts as a protector of pigments preserving them from chemical and biochemical oxidation. Ascorbic acid can react either with the radicals generated in chemical ways, or it can regenerate polyphenols from their oxidized forms due to its antioxidant potential. In order to obtain synergy via regeneration reactions must compete efficiently with the other reactions in which ascorbic acid is oxidized. Based on the standard reduction potentials, it has been predicted and confirmed by kinetic studies that ascorbate regenerates plant phenolic compounds in homogenous solutions from their oxidized form. Polyphenols have a higher redox potential than ascorbate and consequently oxidize it to the ascorbyl radical. Miller and Rice-Evans [21] studied orange, apple and blackcurrant drinks and concluded that phenolic constituents of beverages can retard the oxidative decomposition of vitamin C.

Cysteine is capable of acting as an antioxidant with respect to the reactive oxygen species: superoxide and peroxoradicals and hydroxyl radicals. The reactivity of physiological significance was at sulfur centre. The mechanism of this interaction involves the formation of the cysteine dimer via the thyl radicals by mopping up harmful oxidants. The dimer can be reduced back to the cystine through an appropriate $2 \mathrm{e}$ - reduction such that cysteine can continue to moderate radical toxicity and antioxidants can be regenerated [22]. In the same way, -Richard-Forget et al. [23] investigated effect of cysteine and cysteine-quinone addition compound (CQAC) on apple PPO activity by polarography, using 4-methylcatechol, chlorogenic acid, and (-)-epicatechin as substrate and they showed its capacity for phenol regeneration.

Citric and oxalic acids have also slightly increased the antioxidant activities of rocket salads. The effects of citric and oxalic acids on flavanols have been previously considered as both antibrowning and antioxidant agent. The acidification and chelating function of these acids works together. Therefore, it could be correct to persume that citric and oxalic acids have a protective effect on phenolic compounds.

\section{Total phenol content}

Changes in total phenolic content with time in control and $0.1 \%$ ascorbic acid, $0.01 \%$ cysteine, $0.1 \%$ citric acid and $0.1 \%$ oxalic acid at $4{ }^{\circ} \mathrm{C}$ were investigated (Figure 6). Total phenol content showed a decreasing trend with time. Some phenolic compounds are known to be substrates of PPO. The decrease of total phenol content is probably due to oxidation by PPO. In our previous work, the same trend was also observed in fresh cut lettuce samples [9]. 
In the presence of ascorbic acid and cysteine, total phenol content was increased upon regeneration of phenolic compounds. On the other hand, in the presence of oxalic and citric acids, phenol content was increased upon decreasing of $\mathrm{pH}$.

The increase in relative free radical concentration paralled the decrease in total phenol content. The results showed a good correlation between free radical concentration and total phenol content of all samples ( $r>0.93)$.

\section{CONCLUSION}

Enzymatic browning in foods is reasonably well understood, but prevention of browning in not only factor to take into account to be sure of quality. Besides antibrowning property of inhibitors, protection of nutritional properties should be taken into consideration to maintain fresh like quality. From the obtained results, the antioxidant power of leafy vegetables is dependent not only on the phenol content at the harvest, but it is significantly affected by storage. Therefore, inhibitors can be used to prevent loss of antioxidant activity and antioxidants, such as polyphenols. Ascorbic acid, cysteine, citric acid and oxalic acids prevent browning of rocket salad. In addition, ascorbic acid increase the total antioxidant activity of rocket salad significantly. As a consequence, formulations including additives have to be optimized to succeed in the control of enzymatic browning and loss of nutritional quality

\section{References}

1. L.Hooper, A. Cassidy, A review of the health care potential of bioactive compounds, J. Sci. Food Agri., 86 (2006) 18051813.

2. Y.T.Szeto, T.C.Kwok, I.F.Benzie. Effects of a long-term vegetarian diet on biomarkers of antioxidant status and cardiovascular disease risk, Nutrition, 20 (2004) 863-866

3. J.K. Brecht., M.E. Slatveit, S.T. Tacoltt, K.R.Schneider, K.Felkey, J.A. Bartz, Fresh-cut vegetables and fruits, Hortic Rev., 30 (2004) 185-250.

4. M.E. Saltveit, Physical physiological changes in minimally processed fruits and vegetables. In phytochemistry of fruit and vegetables; Tomas-Barberan, F.A., Robins, R.J., Eds.; Oxford University Press: London, 1997.

5. F.A. Tomas-Barberan, M.Gill, M.Castaner, F. Artes, M.E. Saltveit, Effect of selected browning inhibitors on phenolic metabolism in stem tissue of harvested lettuce, J. Agri. Food Chem., 45(1997) 583-589.

6. M.E. Saltveit, Chilling injury is reduced in cucumber and rice seedlings and in tomato pericarp discs by heat-shocks applied after chilling, Postharvest. Biol. Technol., 21 (2000) 169-177.
7. A.G. Ponce, C.E. Del Valle, S.I. Rural, Natural essential oils as reducing agents of peroxidase activity in leafy vegetables, Lebensm-Wiss Technol., 37 (2004) 199-204.

8. E. Degl'Innocenti, A. Pardossi, F.Tattini, L. Guidi, Phenolic compounds and antioxidant power in minimally processed salad, J. Food Biochem., 32 (2008) 642-653.

9. 9- A. Altunkaya, V. Gökmen, Effect of various inhibitors on enzymatic browning, phenol content and total antioxidant activity of fresh lettuce (L. sativa), Food Chem., 107 (2008) 1173-1179.

10. M.A., Bradford, A rapid and sensitive method for the quantitation of microgram quantities of protein utilizing the principle of protein-dye binding, Anal. Biochem., 72 (1976) 248-254.

11. H. Lineweaver, D. Burk, The determination of enzyme dissociation constants, J. Am. Chem. Soci., 56 (1934) 658666.

12. M.A. Amerine, C.S. Ough, Methods for analysis of musts and wines, Wiley, Newyork. 1980.

13. U. Gawlik-Dziki, U. Zotek, M.O. Ewieca, Characterization of polyphenol oxidase from butter lettuce (Lactuca sativa var. capitata L.), Food Chem., 107 (2008) 129-135.

14. R.K.: Scopes, Protein Purification: Principles and Practice, Springer-Verlag, Berlin, Germany 1987.

15. C.T. Mant, R.S. Hodges, High Peformance liquid chromatography of peptides and proteins: separation, analysis and conformation, CRC Press, Boca Raton, FL, USA, 1991.

16. K.M. Mdluli, Partial purification and characterisation of polyphenol oxidase and peroxidase from marula fruit (Sclerocarya birrea subsp. Caffra), Food Chem., 92 (2005) 311-323.

17. S. Dogan, M. Dogan, Determination of kinetic properties of polyphenol oxidase from Thymus (Thymus longicaulis subsp. Chaubardii var. chaubardii), Food Chem., 88 (2004) 69-77.

18. F. Aylard, D. R. Haisman, Oxidation systems in fruits and vegetables-their relation to the quality of preserved products, Anal. Biochem., 72 (1969) 248-258

19. D. Kavrayan, T. Aydemir, Partial purification and characterization of polyphenoloxidase from peppermint ( ). Food Chem., 74 (2001) 147-154.

20. S.V. Jovanovic, S. Steenken, M. Tosic, B. Marjanovic, M.G. Simic, Flavonoids as antioxidants, J. Am. Chem. Soci., 116 (1994) 4846-4851.

21. C. Kandaswami, J.R. Middleton, Free radical scavenging and antioxidant activity of plant flavonoids, Adv. Exp. Med. Biol. 366 (1994) 351-376.

22. N.J. Miller, C. Rice-Evans, The relative contributions of ascorbic acid and phenolic antioxidants to the total antioxidant activity of orange and apple fruit juices and blackcurrant drink, Food Chem., 60 (1997) 331-337.

23. J. Darkwa, C. Mundoma, R.H. Simoti, Antioxidant chemistry reactivity and oxidation of $\mathrm{DL}$ cysteine by some common oxidants, J. Chem. Soc.Faraday Transac., 94 (1998) 19711978.

24. F.C. Richard-Forget, P.M. Goupy, J.J. Nicolas, Cysteine as an inhibitor of enzymatic browning 2. Kinetic studies, J. Agric. Food Chem., 40 (1992) 2108-2113. 